\title{
Enterovirus and Parechovirus meningitis in children: a review of the epidemiology, diagnostic challenges, and significance of on-site CSF virology tests in tropical paediatric patients' care
}

\author{
${ }^{1,2}$ Kabuga, A. I., ${ }^{1}$ Nejati, A., and ${ }^{* 1,3}$ Shahmahmoodi, S. \\ ${ }^{1}$ Department of Virology, School of Public Health, Tehran University of Medical Sciences, Tehran, Iran \\ ${ }^{2}$ Department of Medical Microbiology and Parasitology, Faculty of Clinical Sciences, College of Health Sciences, \\ Bayero University, PMB 3011 Kano, Kano State, Nigeria \\ ${ }^{3}$ Food Microbiology Research Center, Tehran University of Medical Sciences, Tehran, Iran \\ *Correspondence to: shahmahmoodi@tums.ac.ir; +989121909972
}

\begin{abstract}
:
Enteroviruses and Parechoviruses are increasingly recognized as the cause of aseptic meningitis, especially in the paediatric age group. However, because of indistinguishable clinical features with bacterial meningitis, many clinicians cannot make a clear distinction in disease presentation, and a large number of cases go undiagnosed. Although polymerase chain reaction is the current standard diagnostic approach, it takes many hours or days to get a result and these tests are not available at primary and secondary levels of care in many resource-poor countries. Furthermore, diagnosis is often difficult in children due to nonspecific cellular and biochemical cerebrospinal fluid findings. Some affected children may develop neurologic or/and systemic complications, resulting in prolonged hospital admission, increasing the risk of avoidable deaths, and healthcare expenditures. This review focuses on epidemiology, presentation, and diagnosis of Enterovirus and Parechovirus meningitis, highlighting the challenges in diagnosis and the potential roles of on-site CSF virology tests in improving the quality of paediatric patient's care. The information provided should help early case detection, thereby ensuring avoidance of unnecessary antibiotics, minimal complications, a short period of hospital stays, and a reduction in healthcare-associated costs.
\end{abstract}

Keywords: Aseptic meningitis; Enterovirus; Parechovirus; Diagnostic challenge; On-site virology test; Children

Copyright 2021 AJCEM Open Access. This article is licensed and distributed under the terms of the Creative Commons Attrition 4.0 International License $<$ a rel="license" href="http://creativecommons.org/licenses/by/4.0/", which permits unrestricted use, distribution and reproduction in any medium, provided credit is given to the original author(s) and the source. Editor-in-Chief: Prof. S. S. Taiwo

\section{Méningite à Entérovirus et Parechovirus chez les enfants: un examen de l'épidémiologie, des défis diagnostiques et de l'importance du tests virologique sur site du LCR dans les soins aux patients pédiatriques tropicaux}

\author{
1,2Kabuga, A. I., ${ }^{1}$ Nejati, A., et * 1,3Shahmahmoodi, S.
}

${ }^{1}$ Département de virologie, École de santé publique, Université des sciences médicales de Téhéran, Téhéran, Iran ${ }^{2}$ Département de microbiologie médicale et parasitologie, Faculté des sciences cliniques, Collège des sciences de la santé, Université de Bayero, PMB 3011 Kano, État de Kano, Nigéria

${ }^{3}$ Centre de recherche en microbiologie alimentaire, Université des sciences médicales de Téhéran, Téhéran, Iran *Correspondance à: shahmahmoodi@tums.ac.ir; +989121909972

\begin{abstract}
Abstrait:
Les entérovirus et les parechovirus sont de plus en plus reconnus comme la cause de la méningite aseptique, en particulier dans le groupe d'âge pédiatrique. Cependant, en raison des caractéristiques cliniques indiscernables de la méningite bactérienne, de nombreux cliniciens ne peuvent pas faire une distinction claire dans la présentation de la maladie, et un grand nombre de cas ne sont pas diagnostiqués. Bien que la réaction en chaîne par polymérase soit l'approche diagnostique standard actuelle, il faut plusieurs heures ou jours pour obtenir un résultat et ces tests ne
\end{abstract}


sont pas disponibles aux niveaux de soins primaires et secondaires dans de nombreux pays pauvres en ressources. En outre, le diagnostic est souvent difficile chez les enfants en raison de découvertes non spécifiques du liquide céphalo-rachidien cellulaire et biochimique. Certains enfants atteints peuvent développer des complications neurologiques ou systémiques, entraînant une hospitalisation prolongée, augmentant le risque de décès évitables et les dépenses de santé. Cette revue se concentre sur l'épidémiologie, la présentation et le diagnostic de la méningite à entérovirus et parechovirus, mettant en évidence les défis du diagnostic et les rôles potentiels des tests virologiques sur place dans le LCR dans l'amélioration de la qualité des soins aux patients pédiatriques. Les informations fournies devraient contribuer à la détection précoce des cas, garantissant ainsi d'éviter les antibiotiques inutiles, des complications minimales, une courte période d'hospitalisation et une réduction des coûts associés aux soins de santé.

Mots clés: méningite aseptique; Entérovirus; Parechovirus; Défi diagnostique; Test de virologie sur place; Enfants

\section{Introduction:}

Despite advances in antimicrobials, infections of the central nervous system (CNS) remain a major cause of many life-threatening disease conditions, with aseptic meningitis at the forefront, especially in the paediatric age group. Aseptic meningitis (AM) is an acute inflammation of meninges of the brain and spinal cord in which the cerebrospinal fluid (CSF) is negative for bacteria (1). AM is specifically caused by Enteroviruses (EVs) and Parechoviruses (PeVs), however, viruses such as Herpes simplex virus types I \& II (HSV I \& II), Varicella zoster virus (VZV), Adenovirus (ADV), Rhinovirus (RHV), Epstein Barr virus (EBV), Cytomegalovirus (CMV), Mumps virus, Human herpesvirus 6 ( $\mathrm{HHV} 6$ ) and HIV have been implicated (2-11). Also, there are non-viral causes such as drugs (12-14), parasites, fungi, and inflammatory diseases (7-9). EBV and Cryptococcus are recovered mostly in immunocompromised individuals (9).

EVs and PeVs are emerging pathogens that constitute two important genera (Entero virus and Parechovirus) of the Picornaviridae family. The family of picornaviruses consists small $(\approx 30 \mathrm{~nm})$, non-enveloped viruses containing single-stranded, linear, positive-sense RNA, with several important human and animal pathogens including Polio viruses $(15,16)$. Enterovirus genus consists of 15 species [EV: (A-L) and Rhinovirus (RV: A-C)], and over 100 serotypes have been described $(17,18)$. The genus Parechovirus contains four species; Parechovirus A, formally Human Parechovirus (HPeV), Parechovirus B (formerly Ljungan virus infecting rodents), Parechovirus $C$ (Sebokele virus), and Parechovirus D (Ferret Parechovirus). Nineteen different genotypes of PeV-A have so far been described and their count is still on the increase $(16,19-21)$.

Because of their pathogenic potential, increasing frequency of detection (even among healthy individuals), and the ability to cause severe infections, EVs and PeVs attracted more attention and became relevant globally (1927). But, without clear distinction in clinical presentation and non-specific CSF findings, diagnosis of AM is rarely considered, and only when the first line of care (usually antibiotic therapy) fails (28-32). The situation is worsening in countries with poor laboratory diagnostic services and inadequate intensive care facilities.

The on-site CSF virology tests eliminate the technicalities of sample preparation and processing and produce results in a matter of minutes. They offer a superior advantage in patients' management through early recognition of cases and exclusion of other suspected pathogens. Reduction in the use of unnecessary antibiotics, expendable costly investigations, as well as guiding investigations and follow-up for potential complications in severely affected children are among added benefits $(29,31,33)$. In this review, we provided a summary of current knowledge on Enterovirus and Parechovirus meningitis, with emphasis on the paediatric age group.

\section{Methodology:}

This article is a narrative review of Enterovirus and Parechovirus meningitis available in the literature. Original and review articles published in English Language were searched for on PubMed, Embase, Scopus, and Google Scholar. Articles reporting information relating to the biology and classification of Enterovirus and Parechovirus, epidemiology, clinical presentations, and laboratory diagnosis of meningitis caused by these viruses, as well as the diagnostic challenges, and the potential roles of on-site CSF virology tests were retrieved and reviewed.

\section{Epidemiology of Enteroviruses and Parecho- viruses}

Human EVs and PeV-A are ubiquitous, transmitted mainly by direct contact with respiratory secretions, droplets, nasal discharge, sputum, saliva, or faeces, from symptomatic or asymptomatic carriers, within a family, in schools, hostels, and chronic care facilities (3439). Nosocomial $(40,41)$, and transplacental 
transmission $(24,42)$ have been reported. They cause several diseases in humans (sporadic and endemic) and have the potential for pandemic spread $(25,43,44)$. However, the exact disease incidence is not known. Reports vary by country, demographic characteristics, and virus genotype. EVs typically infects older children and adults while the PeVs predominate in neonates and infants $(20,21,31,38,45-52)$. A pooled-data from Japan, Hong Kong, Denmark, Finland, Netherlands, the USA, and Malawi revealed a prevalence of $\approx 2 \%$ for PeV$A$ in children with suspected viral infections $(35,44,52)$. In under-developed nations, data are limited because the diagnostic facilities are difficult to operationalize and only restricted to referral laboratories. In tropical Africa, reliable data are only available in countries with good research-link $(9,18,19,30,36,39,52-59)$.

From a recent study in the UK and the Republic of Ireland, the incidence of EV-PeV meningitis was twice that of bacterial meningitis (24). AM is more prevalent during the hot season, usually May to September $(10,24,60-$ $63)$, but can occur all-year-round (10,49, 56,63-67). Cases are seen mostly in children less than five years of age $(50,63)$, more males affected than females, and there may be variation in the distribution $(30,55,62,63,65)$. The infection accounts for many admissions into intensive care units, with associated mortality $(11,24,29,49,61,68-70)$. The summary of the detection rates from various countries is shown in Table 1.

Table 1: Detection rates of Enterovirus (EV) and Parechovirus ( $\mathrm{PeV}$ ) in children with suspected meningitis from various countries

\begin{tabular}{|c|c|c|c|c|c|c|c|}
\hline \multirow[t]{2}{*}{ Country } & \multirow{2}{*}{$\begin{array}{l}\text { Place of study } \\
\text { (province/state/city) }\end{array}$} & \multirow[t]{2}{*}{ Study period } & \multirow{2}{*}{$\begin{array}{l}\text { Targeted age } \\
\text { (Mean/Median) }\end{array}$} & \multicolumn{2}{|c|}{ Prevalence (\%) } & \multirow{2}{*}{$\begin{array}{l}\text { Most affected } \\
\text { age (Median) }\end{array}$} & \multirow[t]{2}{*}{ Reference } \\
\hline & & & & EV & PeV & & \\
\hline \multirow[t]{2}{*}{ Australia } & Western Australia & Feb-Jul 1992 & $<15$ years & $80 / 104(76.9)$ & & $<5$ years & $(28)$ \\
\hline & São Joaquim da Barra & Dec 1998-Dec 2003 & $2-6$ years & $64 / 294(21.8)$ & & $1-4$ years & (64) \\
\hline \multirow[t]{2}{*}{ Brazil } & São Paulo & Feb-May 2004 & 4.5 years & $12 / 23(52.2)$ & & & $(118)$ \\
\hline & São Paulo & $2008-2009$ & $\leq 5$ years & $49 / 344(14.2)$ & & & (4) \\
\hline \multirow[t]{3}{*}{ Canada } & Alberta, Manitoba, $¥$ & Jan 1998-Dec 1999 & $<1$ to 18 years & $233 / 802(29.1)$ & & & (119) \\
\hline & Yunnan & $2009-2010$ & $3-14$ years & $85 / 524(16.2)$ & & $<14$ & $(76)$ \\
\hline & Luoding, Guangdong & May-Jun 2012 & 6 years & $75 / 121(62)$ & & $3-5$ years & (74) \\
\hline \multirow[t]{3}{*}{ China } & Shandong & 2014 & & $209 / 927(22.5)$ & & & (63) \\
\hline & Zhejiang & 2002 to 2015 & & $206 / 1757$ (11.7) & & & (120) \\
\hline & Hebei & Jan-Sept 2015 & 7 months -16 years & $89 / 268(33.2)$ & & & $(10)$ \\
\hline Denmark & & $2009-2012$ & $<5$ years & & $30 / 32(94)$ & 39 days & $(47)$ \\
\hline \multirow{2}{*}{ Egypt } & Cairo & Jun 2010-May 2012 & 1.5 months- 12 years & & $56 / 100(56)$ & $<2$ years & (30) \\
\hline & Clermont-Ferrand & Jan 2008-Dec 2009 & $2-16$ years & $17 / 27(63)$ & & 32 days- 2 years & (121) \\
\hline \multirow[t]{2}{*}{ France } & Clermont-Ferrand & $\begin{array}{l}\text { Jun 2015-Oct } 2015 \\
\text { Jun 2016-Oct } 2016\end{array}$ & $\leq 28$ days- 16 years & $222 / 246(90.2)$ & & $2-16$ years & (77) \\
\hline & Bonn & May $1998-O c t 2008$ & 8 days -17 years & $14 / 327(4.3)$ & $2 / 327(0.6)$ & $<3$ months & $(6)$ \\
\hline \multirow[t]{2}{*}{ Germany } & Hannover, $€$ & $\begin{array}{l}2008 \\
2013\end{array}$ & $0-18$ years & $\begin{array}{l}100 / 157(63.7) \\
96 / 106(90.6)\end{array}$ & & $\begin{array}{l}6.8 \pm 3.8 \text { years } \\
7.1 \pm 4.1 \text { years }\end{array}$ & (71) \\
\hline & Athens metropolitan & Jan 1994-Dec 2002 & 1 month-14 years & $47 / 96(49)$ & & $6-12$ years & $(93)$ \\
\hline \multirow[t]{4}{*}{ Greece } & Thessaloniki, $£$ & Mar 2003-Apr 2005 & 21 days -14 years & $14 / 32(43.8)$ & & 7.73 years & (82) \\
\hline & Athens & 2007 & $0-15$ years & $105 / 177(59.3)$ & & $5.2-7.5$ years & (83) \\
\hline & Nemazi, Dastgheib & May 2001-May 2002 & 2 months -15 years & $13 / 102(12.7)$ & & 8 month-12 year & $(122)$ \\
\hline & Mashhad city & Mar-Sept. 2007 & $<1$-month -17 years & $21 / 58(36.2)$ & & 5.7 years & $(70)$ \\
\hline \multirow[t]{4}{*}{ Iran } & Shiraz & May 2007-Apr 2008 & 2 months-15 years & $13 / 65(20)$ & & $1-5$ years & (3) \\
\hline & Tehran & $2007-2012$ & $<8$ years & $275 / 366(75.1)$ & $154 / 366(42)$ & $20.17 \mathrm{~m}:>1$ year & (84) \\
\hline & Tehran & $2009-2011$ & $<8$ years & $24 / 115(20.87)$ & $51 / 115(44)$ & $20.12 \mathrm{~m}: 26.67 \mathrm{~m}$ & (92) \\
\hline & Northern Iran & Jun 2014: Mar 2015 & 6 months -13 years & $9 / 50(18)$ & & 2-5 years & $(123)$ \\
\hline Italy & San Matteo, Pavia & Jan 2010-Oct 2013 & $<30$ days & $4 / 60(6.7)$ & & & $(61)$ \\
\hline Netherlands & Tilburg and Breda & Mar 2008-Aug 2011 & $0-16$ years & $75 / 141(53.2)$ & $16 / 141(11.3)$ & 50 days: 34 days & $(45,124)$ \\
\hline \multirow[t]{2}{*}{ Palestine } & West Bank & July 2012- Nov 2015 & $<1-10$ years & $62 / 324(19.1)$ & & $<1$ year & $(88)$ \\
\hline & Northern West Bank & Mar-Oct 2017 & $0-92$ months & $54 / 249(21.7)$ & & $0-92$ months & $(62)$ \\
\hline Russia & West Siberia & $2012-2013$ & $1-14$ years & $70 / 143(50)$ & & & $(86)^{\prime}$ \\
\hline South Africa & Mossel Bay, W. Cape & Dec 2015-Jan 2016 & $<10$ years & $43 / 63(68.3)$ & & $2-4$ years & (55) \\
\hline \multirow[t]{2}{*}{ South Korea } & Chungcheong & Jun-Oct 2008 & $\leq 16$ years & $60 / 140(42.9)$ & & $2 \mathrm{~m}-13$ years & (125) \\
\hline & Jinju & Feb 2012-Sept. 2013 & $1-5$ years & $20 / 267(0.7)$ & $9 / 267(3.4)$ & $1.4 \mathrm{~m}: 7.8 \mathrm{~m}$ & $(75)$ \\
\hline \multirow{4}{*}{ Turkey } & Monastir \& Mahdia & Jan 2011-Jan 2013 & $<28$ days -16 years & $14 / 143(9.8)$ & & $2-16$ years & (85) \\
\hline & Ankara & Jun 1999-Dec 2004 & $<1-14$ years & $104 / 612(17)$ & & $5.6 \pm 3.4$ year & $(2)$ \\
\hline & London & $2008-2012$ & $<1$ years & & $30 / 40(75)$ & $<90$ days & (31) \\
\hline & Cornwall & $2012-2015$ & $\leq 5$ years & $20 / 98(20.4)$ & & $<5$ months & $(60)$ \\
\hline \multirow[t]{3}{*}{ UK } & & 2016 & $\leq 5$ years & $27 / 140(19.3)$ & $14 / 140(10)$ & $<5 \mathrm{~m}:<2 \mathrm{~m}$ & \\
\hline & England & 2016 & $3-150$ days & & $104 / 106(98)$ & $<90$ days & $(48)$ \\
\hline & Leicester & Feb 2014-Aug 2017 & 29-102 days & $131 / 163(80.4)$ & $32 / 163(19.6)$ & $<90$ days & (49) \\
\hline UK \& Ireland & Wales \& North Ireland & Jul 2014-Aug 2015 & $<90$ days & $668 / 703(95)$ & $35 / 703(5)$ & 34 days & $(24)$ \\
\hline USA & 8 Regions & Feb-Sept. 2014 & $<2$ months-17years & $47 / 639(2.7)$ & $12 / 299(4)$ & $<2$ months & (8) \\
\hline
\end{tabular}


Socio-demographic factors such as age, gender, season, and study design accounted for substantial disparity in disease prevalence, in countries, and regions within the same country, with studies mostly on EVs. Estimates indicated variation in peak age of the infection, but mostly within the first five years of life $(\leq 5$ years for EVs versus $<3$ months for PeVs). It is important to note that symptoms in neonates are subtle and not different from sepsis-like illnesses, which leads to a serious challenge in diagnosis and reporting, suggesting the need for high-quality surveillance to optimize detection, as countryspecific estimates are crucial tools to improve diagnostics and therapeutics for these infections.

Prevailing genotypes/serotypes of EVs and PeVs involved in AM and other infections On specific serotypes, Coxsackievirus B5 (CVB5), Coxsackievirus A9 (CVA9), Echovirus 6, 9, and 30 and CVB3 are the most commonly reported serotypes from $A M$ and other clinical infections $(49,55,63,64,71-78)$. Other serotypes recovered include Echovirus 1 , $3,4,5,7,11,13-16,18,20,25,27,32$ and 33; CVB1, CVB2, CVB4, CVB6; CVA2, CVA4-6, CVA10, CVA15, CVA16, CVA21 and EV71 (6, $10,28,45,49,55,56,60-67,71-73,75,76,79-89)$. On the other hand, PeV-A3 is the mostly recovered genotype $(31,47-50,60,90,91)$ while other genotypes recovered are PeV-A 2 and 1 $(47,92)$.

\section{Clinical presentations of meningitis caused by EVs and PeVs and complications}

Usually, there is no clear distinction in clinical presentations of meningitis caused by $\mathrm{EV}, \mathrm{PeV}$, or bacteria agents. Fever is the most common symptom and is usually moderate to high grade. Nausea, vomiting, diarrhea, poor feeding, irritability, convulsions, headache, and altered level of consciousness are notable symptoms $(24,31,56,60-64,71,77,82,93-95)$. Headache, vomiting, neck rigidity, and lethargy are pronounced in children with EV meningitis (77, 94,96). Patients may present with typical features of upper respiratory tract infections, and maculopapular rashes mostly in those with PeV infections $(31,60,97)$.

The severity and risk of developing complications depend on the virus type, patient age, and the interval between disease onset and presentation to the physician (31, $32,94,98,99)$. Abnormalities of the white matter and neurodevelopmental delays are the common sequelae $(24,31,32,47,50,51,91,98$,
$100,101)$. Subdural hemorrhage, coronal infartion, cystic encephalomalacia, periventricular leukomalacia, and ventricular dilatations are specific complications. Such patients may manifest with failure to thrive (FTT), recurrent seizures, visual impairment, and global hypotonia $(11,24,31,49,91,102)$. Hyponatremia due to the syndrome of inappropriate antidiuretic hormone secretion (SIADS) has been reported (70). Shaker and Abdelhamid reported 50\% mortality in patients who tested positive for EV (30), while some other studies also reported considerable mortalities $(24,31,70)$.

\section{Laboratory diagnosis of EVs/PeVs infections and challenges}

Laboratory testing is essential for the definitive diagnosis of infectious meningitis, particularly in the young infant, because clinical disease presentation lacks predictive value. CSF pleocytosis and elevated protein are the recommended criteria for diagnosis, however, many studies showed varied results $(10$, $24,28-32,56,60,73,75,88,91)$. With contradicttory reports of other markers such as C-reactive protein (CRP), lactate, mononuclear, or polymorphonuclear cells counts $(24,91,103$, 104), there could be uncertainty in diagnosis and treatment. Therefore, it should be noted that with the positive signs and symptoms of meningitis, the absence of CSF pleocytosis, elevated protein, or other markers of interest does not rule out EV or PeV meningitis.

The mainstay of the diagnosis is molecular-based assays on appropriately collectedsamples. Cell culture is one of the most popular methods for virus isolation, evidenced by the cytopathic effect (CPE), which alter specific characteristics of the cells. However, cultures are intensive and some viruses (most especially PeVs) do not replicate in commonly used cell lines. Thus, researchers nowadays are reluctant to use cultures and tend to adopt PCR techniques for relative simplicity and short window for results $(21,23)$. Recently, we evaluated the diagnostic sensitivity of cell culture, real time RT PCR, and nested RT PCR for EVs and PeVs, and real time RT PCR demonstrated the highest sensitivity and negative predictive value (NPV), particularly for EVs (unpublish work). Specifically, real-time PCR is the recommended test for EVs and PeVs in all clinical specimens $(21,23)$. The PCR assay relies on the extraction and purification of nucleic acid, then exponential amplification of the target sequence, using a thermostable polymerase and specific primers.

Unfortunately, most tropical and sub- 
tropical countries cannot establish qualitative molecular-based diagnostic tests in basic healthcare settings. This contributes to the enormous burden of ill health as infectious diseases represent the major cause of death in most of the countries. Another fundamental problem is the lack of incorporation of EVs and PeVs among the list of priority infections. This significantly deterred identification of the pathogens even in developed nations. Therefore, misdiagnosis and failure to treat a serious infection or wasting expensive treatment on those not infected remain a serious obstacle. Even without targeted treatment, early identification of infections has economic benefits, which include stopping the use of unnecessary antimicrobial drugs, minimizing expendable investigations, and shortening the length of hospital admissions $(24,105,106)$.

\section{On-site CSF virology tests and management of $E V$ and $P e V$ infections}

The WHO has established the ASSURED (Affordable, Sensitive, Specific, User friendly, Rapid, and robust, Equipment-free, and Deliverable to end-users) criteria (107) for diagnostics in a resource-poor setting. This aimed at providing better management of diseases through immediate delivery of results and a rapid record of the disease status, improve clinical decision-making. The costeffective on-site CSF virology tests employ reverse-transcriptase polymerase chain reaction to rapidly identify the presence of viral RNA in CSF of a suspected infected individual. These offer superior advantages over conventional nested PCR and real-time PCR by providing prompt identification of the pathogen, guide selection of therapy, and minimize complications. Added advantages include short time window for results (rapid turnaround time), antimicrobial stewardship through appropriate prescribing practice, reduction in financial costs, and improve patient outcomes $(8,9,108-114)$. Additionally, the WHO recommended criteria of the physical structure and human resources as key elements of a virology laboratory (115) can be adjusted to suit the desired need in a particular setting, hence, guaranteeing the feasibility of carrying out these tests in most of our local clinics and hospitals.

Currently, there are no antiviral agents licensed for the treatment of EVs and PeVs infections, but vaccines are available only against PVs, and China licensed an EV71 vaccine in December 2015 (116). Researchers are currently exploring the potential benefits of intravenous immunoglobulins (IVIGs), predni- solone, and other compounds in the management of EVs and PeVs infections. Of recent, a compound 2'-C-methylcytidine, an inhibitor of viral polymerase, demonstrated promising results against PeA-1 and 3 in-vitro (117).

\section{Conclusion:}

Enteroviruses and Parechoviruses are the leading causes of aseptic meningitis, and there exist indistinguishable presentations with bacterial meningitis, while CSF pleocytosis and biochemical tests show limited roles in diagnosis. The disease prevalence varies in different geographical regions, mainly affected by socio-demographic factors, and E9, 30, 6, 16, CVB5, CVA9, CVB3, and PeV-A3 are commonly isolated virus serotypes. Although the WHO recommends syndromic management in settings with limited access to laboratory diagnostic services, the economic burden of treating common causes of the syndrome is outrageous and merely impossible in local settings. With the evolution of high precision point-of-care CSF virology tests, stockholders should explore their benefits to optimize the quality of care in children with EVs and PeVs meningitis, most especially in resource-poor settings.

\section{Acknowledgment:}

Tehran University of Medical Sciences, International Campus, supported this work

\section{Conflict of interest:}

Authors declare no conflict of interest.

\section{References:}

1. Han, S. H., Choi, H. Y., Kim, J. M., Park, K. R. Youn, Y. C., and Shin, H. W. Etiology of aseptic meningitis and clinical characteristics in immune-competent adults. J Med Virol. 2016; 88 (1): $175-179$

2. Şensoy, G., Sel, K., Özkaya, E., Çakir, B. Ç. Vidinlisan, S., and Doganci, L. Enteroviral meningitis in children in Turkey. Cent Eur J Med. 2009; 4 (2): 253-258.

3. Hosseininasab, A., Alborzi, A., Ziyaeyan, M., et al. Viral etiology of aseptic meningitis among children in southern Iran. J Med Viro. 2011; 83 (5): 884888.

4. Casaroto, E., Marra, A. R., Coelho, F. M. S., et al Improving the diagnosis of meningitis due to enterovirus and herpes simplex virus I and II in a tertiary care hospital. BMC Infect Dis. 2013; 13 (1): 487.

5. Akya, A., Ahmadi, K., Zehtabian, S., Salimi, A. Elahi, A., and Madani, S. H., Study of the frequency of herpesvirus infections among patients with suspected aseptic meningitis 
in the West of Iran. Jundishapur J Microbiol. 2015; 8 (10): e22639.

6. Vollbach, S., Müller, A., Drexler, J. F., et al. Prevalence, type and concentration of human enterovirus and parechovirus in cerebrospinal fluid samples of pediatric patients over a 10-year period: a retrospective study. Virol J. 2015; 12 (1): 199.

7. Jarrin, I., Sellier, P., Lopes, A., et al. Etiologies and management of aseptic meningitis in patients admitted to an internal medicine department. Medicine (Baltimore). 2016; 95 (2): e2372.

8. Leber, A. L., Everhart, K., Balada-Llasat, J-M., et al. Multicenter evaluation of Biofire FilmArray meningitis/encephalitis panel for detection of bacteria, viruses, and yeast in cerebrospinal fluid specimens. J Clin Microbiol. 2016; 54 (9): 22512261.

9. Rhein, J., Bahr, N. C., Hemmert, A. C., et al. Diagnostic performance of a multiplex PCR assay for meningitis in an HIV-infected population in Uganda. Diagn Microbiol Infect Dis. 2016; 84 (3): $268-273$.

10. Chen, X., Li. J., Guo, J., Xu, W., Sun, S., and Xie, Z., An outbreak of echovirus 18 encephalitis/ meningitis in children in Hebei Province, China, 2015. Emerg Microbes Infect. 2017; 6 (1): 1-3.

11. Ferreras Antolín, L., Kadambari, S., Braccio, S., et al. Increased detection of human parechovirus infection in infants in England during 2016: epidemiology and clinical characteristics. Arch Dis Childhood. 2018; 103 (11): 1061-1066.

12. Frank-Briggs, A., and Oluwatade, O. Drug induced aseptic meningitis: a diagnostic challenge. Nig Paediatr. 2014; 41 (2): 138-140.

13. Morís, G., and Garcia-Monco, J. C. The challenge of drug-induced aseptic meningitis revisited. JAMA Intern Med. 2014; 174 (9): 1511-1512.

14. Pires, S. A. P., Lemos, A. P., Pereira, E. P. M. N., and Maia PAdSV. Ibuprofen-induced aseptic meningitis: a case report. Revista Paulista de Pediatr. 2019; 37 (3): 382-385.

15. Stellrecht, K. A., Lamson, D. M., and Romero, J. R. Enteroviruses and parechoviruses. Manual of Clinical Microbiology, Eleventh Edition: American Society of Microbiology; 2015: 1536-1550.

16. Cifuente, J. O., and Moratorio, G. Evolutionary and structural overview of human picornavirus capsid antibody evasion. Front Cell Infect Microbiol. 2019; 9: 283

17. Nikonov, O., Chernykh, E., Garber, M., and Nikonova, E. Y. Enteroviruses: classification of diseases they cause, and approaches to development of antiviral drugs. Biochemist (Moscow). 2017; 82 (13): 1615-1631.

18. Adewumi, O., Olayinka, O., and Adeniji, J. Genomic Characterization of a Coxsackievirus A20 Strain Recovered from a Child with Acute Flaccid Paralysis in Nigeria. Microbiol Resour Announc. 2019; 8 (42): e00849-19.

19. Graul, S., Böttcher, S., Eibach, D., et al. High diversity of human parechovirus including novel types in stool samples from Ghanaian children. J Clin Virol. 2017; 96: 116-119.

20. Olijve, L., Jennings, L., and Walls, T. Human parechovirus: an increasingly recognized cause of sepsis-like illness in young infants. Clin Microbiol Rev. 2018; 31 (1): e00047-17.

21. Kadambari, S., Harvala, H., Simmonds, P., Pollard A. J., and Sadarangani, M. Strategies to improve detection and management of human parechovirus infection in young infants. The Lancet Infect Dis. 2019; 19 (2): e51-e58.

22. Nelson, T. M., Vuillermin, P., Hodge, J., et al. An outbreak of severe infections among Australian infants caused by a novel recombinant strain of human parechovirus type 3. Sci Rep. 2017; 7: 44423.

23. Harvala, H., Broberg, E., Benschop, K., et al. Recommendations for enterovirus diagnostics and characterisation within and beyond Europe. J Clin Virol. 2018; 101: 11-17.

24. Kadambari, S., Braccio, S., Ribeiro, S., et al. Enterovirus and parechovirus meningitis in infants younger than 90 days old in the UK and Republic of Ireland: a British Paediatric Surveillance Unit study. Arch Dis Childhood. 2019; 104 (6): 552-557.

25. Pons-Salort, M., Oberste, M. S., Pallansch, M. A., et al. The seasonality of nonpolio entero viruses in the United States: patterns and drivers. Proc Natl Acad Sci USA. 2018; 115 (12): 3078-3083.

26. Shabani, A., Makvandi, M., Samarbafzadeh, A., et al. Echovirus 30 and coxsackievirus A9 infection among young neonates with sepsis in Iran. Iran J Microbiol. 2018; 10 (4): 258-265.

27. Brouwer, L., Wolthers, K. C., and Pajkrt, D. Parechovirus A prevalence in adults in The Netherlands. Arch Virol. 2020; 165: 963-966.

28. Ashwell, M., Smith, D., Phillips, P., and Rouse, I. Viral meningitis due to echovirus types 6 and 9: epidemiological data from Western Australia. Epidemiol Infect. 1996; 117 (3): 507-512.

29. Khatami, A., McMullan, B. J., Webber, M., et al. Sepsis-like disease in infants due to human parechovirus type 3 during an outbreak in Australia. Clin Infect Dis. 2015; 60 (2): 228-236.

30. Shaker, O. G., and Abdelhamid, N. Detection of enteroviruses in pediatric patients with aseptic meningitis. Clin Neurol Neurosurg. 2015; 129: 6771.

31. Vergnano, S., Kadambari, S., Whalley, K., et al. Characteristics and outcomes of human parechovirus infection in infants (2008-2012). Eur J Pediatr. 2015; 174 (7): 919-924.

32. Britton, P. N., Dale, R. C., Nissen, M. D., et al. Parechovirus encephalitis and neurodevelopmental outcomes. Pediatr. 2016; 137 (2): e20152848.

33. Wolthers, K. C., Benschop, K. S., Schinkel, J., et al. Human parechoviruses as an important viral cause of sepsislike illness and meningitis in young children. Clin Infect Dis. 2008; 47 (3): 358-363.

34. Aizawa, Y., Yamanaka, T., Watanabe, K., Oishi, T., and Saitoh, A. Asymptomatic children might transmit human parechovirus type 3 to neonates and young infants. J Clin Virol. 2015; 70: 105108.

35. Fan, Y-M., Oikarinen, S., Lehto, K-M., et al. High prevalence of selected viruses and parasites and their predictors in Malawian children. Epidemiol Infect. 2019; 147: e90.

36. Oyero, O. G., Adu, F. D., and Ayukekbong, J. A. Molecular characterization of diverse species enterovirus-B types from children with acute flaccid paralysis and asymptomatic children in Nigeria. Virus Res. 2014; 189: 189-193.

37. Nielsen, N. M., Midgley, S. E., Nielsen, A. C. Y., Christiansen, C. B., and Fischer, T. K. Severe human parechovirus infections in infants and the role of older siblings. Am J Epidemiol. 2016; 183 (7): 664-670.

38. Wildenbeest, J. G., Benschop, K. S., Bouma-de Jongh, S., Wolthers, K. C., and Pajkrt, D. Prolonged shedding of human parechovirus in feces of young children after symptomatic infection. Pediatr Infect Dis J. 2016; 35 (5): 580583.

39. Di Cristanziano, V., Böttcher, S., Diedrich, S., et al. Detection and characterization of enteroviruses and parechoviruses in healthy people living in the South of Cote d'Ivoire. J Clin Virol. 2015; 71: 40-43. 
40. Strenger, V., Diedrich, S., Boettcher, S., et al. Nosocomial outbreak of parechovirus 3 infection among newborns, Austria, 2014. Emerg Infect Dis. 2016; 22 (9): 1631-1634.

41. Aizawa, Y., Izumita, R., and Saitoh, A. Human parechovirus type 3 infection: an emerging infection in neonates and young infants. J Infect Chemother. 2017; 23 (7): 419-426.

42. Konstantinidou, A., Anninos, H., Spanakis, N., et al. Transplacental infection of Coxsackievirus B3 pathological findings in the fetus. J Med Virol. 2007; 79 (6): 754-757.

43. Zhang, C., Zhu, R., Yang, Y., et al. Phylogenetic analysis of the major causative agents of hand, foot and mouth disease in Suzhou city, Jiangsu province, China, in 2012-2013. Emerg Microbes Infect. $2015 ; 4$ (1): 1-10.

44. Sridhar, A., Karelehto, E., Brouwer, L., Pajkrt, D. and Wolthers, K. C. Parechovirus A Pathogenesis and the Enigma of Genotype A-3. Viruses. 2019; 11 (11): 1062.

45. de Crom, S. C., Rossen, J., Van Furth, A., and Obihara, C. C. Enterovirus and Parechovirus infection in children: a brief overview. Eur ] Pediatr. 2016; 175 (8): 1023-1029.

46. Esposito, S., Rahamat-Langendoen, J., Ascolese, B., Senatore, L., Castellazzi, L., and Niesters, H. G. Pediatric parechovirus infections. J Clin Virol. 2014; 60 (2): 84-89.

47. Fischer, T. K., Midgley, S., Dalgaard, C., and Nielsen, A. Y. Human parechovirus infection, Denmark. Emerg Infect Dis. 2014; 20 (1): 83-87.

48. Antolín, L. F., Kadambari, S., Braccio, S., et al. Increased detection of human parechovirus infection in infants in England during 2016: epidemiology and clinical characteristics. Arch Dis Childhood. 2018; 103 (11): 1061-1066.

49. Black, S., Bradley, C., Lai, F. Y., et al. Comparing the clinical severity of disease caused by enteroviruses and human parechoviruses in neonates and infants. Pediatr Infect Dis J. 2019; 38 (2): e36-e38.

50. van Hinsbergh, T. M., de Crom, S. C., Lindeboom, R., van Furth, M. A., and Obihara, C. C. Human parechovirus meningitis and gross-motor neurodevelopment in young children. Eur J Pediatr. 2019; 178 (4): 473-481.

51. Britton, P. N., Khandaker, G., Khatami, A., et al. High prevalence of developmental concern amongst infants at 12 months following hospitalised parechovirus infection. J Paediatr Child HIth. 2018; 54 (3): 289-295.

52. Brouwer, L., Karelehto, E., Han, A. X., et al. High frequency and diversity of parechovirus $A$ in a cohort of Malawian children. Arch Virol. 2019; 164 (3): 799-806.

53. Ngure, F. M., Reid, B. M., Humphrey, J. H., Mbuya, M. N., Pelto, G., and Stoltzfus, R. J. Water, sanitation, and hygiene (WASH), environmental enteropathy, nutrition, and early child development: making the links. Ann N Y Acad Sci. 2014; 1308 (1): 118-128.

54. Annan, A., Ebach, F., Corman, V., et al. Similar virus spectra and seasonality in paediatric patients with acute respiratory disease, Ghana and Germany. Clin Microbiol Infect. 2016; 22 (4): 340-346.

55. Smuts, H., Cronje, S., Thomas, J., Brink, D., Korsman, S., and Hardie, D. Molecular characterization of an outbreak of enterovirusassociated meningitis in Mossel Bay, South Africa, December 2015-January 2016. BMC Infect Dis. 2018; 18 (1): 709.

56. Wolfaardt, M., Büchner, A., Myburgh, M., Avenant, T., Du Plessis, N. M., and Taylor, M. B. Molecular characterisation of enteroviruses and clinical findings from a cluster of paediatric viral meningitis cases in Tshwane, South Africa 20102011. J Clin Virol. 2014; 61 (3): 400-405.

57. Sadeuh-Mba, S. A., Bessaud, M., Massenet, D., et al. High frequency and diversity of species $C$ enteroviruses in Cameroon and neighboring countries. J Clin Microbiol. 2013; 51 (3): 759-770.

58. Fernandez-Garcia, M. D., Kebe, O., Fall, A. D., and Ndiaye, K. Identification and molecular characterization of non-polio enteroviruses from children with acute flaccid paralysis in West Africa, 20132014. Sci Rep. 2017; 7 (1): 1-11.

59. Faleye, T. O. C., Adewumi, M. O., Coker, B. A., Nudamajo, F. Y., and Adeniji, J. A. Direct detection and identification of enteroviruses from faeces of healthy Nigerian children using a cellculture independent RT-seminested PCR assay. Adv Virol. 2016; 1-12.

60. Chakrabarti, P., Warren, C., Vincent, L., and Kumar, Y. Outcome of routine cerebrospinal fluid screening for enterovirus and human parechovirus infection among infants with sepsis-like illness or meningitis in Cornwall, UK. Eur J Pediatr. 2018; 177 (10): 1523-1529.

61. Piralla, A., Mariani, B., Stronati, M., Marone, P., and Baldanti, F. Human enterovirus and parechovirus infections in newborns with sepsislike illness and neurological disorders. Early Human Dev. 2014; 90: S75-S77.

62. Dumaidi, K., Al-Jawabreh, A., Samarah, F., Zraiqi, A., and Yaseen, D. Genetic diversity of the enteroviruses detected from cerebrospinal fluid (CSF) samples of patients with suspected aseptic meningitis in northern West Bank, Palestine in 2017. PLoS One. 2018; 13 (12): e0202243.

63. Chen, P., Lin, X., Liu, G., et al. Analysis of enterovirus types in patients with symptoms of aseptic meningitis in 2014 in Shandong, China. Virol. 2018; 516: 196-201.

64. dos Santos, G. P., Skraba, I., Oliveira, D., et al. Enterovirus meningitis in Brazil, 1998-2003. J Med Virol. 2006; 78 (1): 98-104.

65. Mirand, A., Archimbaud, C., Henquell, C., et al. Prospective identification of HEV-B enteroviruses during the 2005 outbreak. J Med Virol. 2006; 78 (12): 1624-1634.

66. Cui, A., Yu, D., Zhu, Z., et al. An outbreak of aseptic meningitis caused by coxsackievirus $A 9$ in Gansu, the People's Republic of China. Virol J. 2010; 7 (1): 72.

67. Pabbaraju, K., Wong, S., Chan, E. N., and Tellier, R. Genetic characterization of a Coxsackie A9 virus associated with aseptic meningitis in Alberta, Canada in 2010. Virol J. 2013; 10 (1): 93.

68. Cordey, S., L'Huillier, A. G., Turin, L., Gervaix, A., Barbe, K. P., and Kaiser, L. Enterovirus and Parechovirus viraemia in young children presenting to the emergency room: Unrecognised and frequent. J Clin Virol. 2015; 68: 69-72.

69. Braccio, S., Kapetanstrataki, M., Sharland, M., and Ladhani, S. N. Intensive care admissions for children with Enterovirus and human Parechovirus infections in the United Kingdom and the Republic of Ireland, 2010-2014. Pediatr Infect Dis J. 2017; 36 (3): 339-432.

70. Shahroodi, M. J. G., Ghazvini, K., Sadeghi, R., and Sasan, M. S. Enteroviral Meningitis in neonates and children of Mashhad, Iran. Jundishapur J Microbiol. 2016; 9 (5): e19955.

71. Rudolph, H., Dernbach, R. P., Walka, M., et al. Comparison of clinical and laboratory characteristics during two major paediatric meningitis outbreaks of echovirus 30 and other non-polio enteroviruses in Germany in 2008 and 2013. Eur J Clin Microbiol Infect Dis. 2017; 36(9): 1651-1660. 
72. Archimbaud, C., Chambon, M., Bailly, J., et al. Impact of rapid enterovirus molecular diagnosis on the management of infants, children, and adults with aseptic meningitis. J Med Virol. 2009; 81 (1): 42-48.

73. Volle, R., Bailly, J-L., Mirand, A., et al. Variations in cerebrospinal fluid viral loads among enterovirus genotypes in patients hospitalized with laboratory-confirmed meningitis due to enterovirus. J Infect Dis. 2014; 210 (4): 576-584.

74. Xiao, H., Guan, D., Chen, R., et al. Molecular characterization of echovirus 30-associated outbreak of aseptic meningitis in Guangdong in 2012. Virol J. 2013; 10 (1): 263.

75. Seo, J-H., Yeom, J. S., Youn, H-S., Han, T-H., and Chung, J-Y. Prevalence of human parechovirus and enterovirus in cerebrospinal fluid samples in children in Jinju, Korea. Korea J Pediatr. 2015; 58 (3): 102.

76. Zhu, Y., Zhou, X., Liu, J., et al. Molecular identification of human enteroviruses associated with aseptic meningitis in Yunnan province, Southwest China. Springerplus. 2016; 5(1): 1515.

77. Lafolie, J., Labbé, A., L'honneur, A. S., et al. Assessment of blood enterovirus PCR testing in paediatric populations with fever without source, sepsis-like disease, or suspected meningitis: a prospective, multicentre, observational cohort study. Lancet Infect Dis. 2018; 18 (12): 13851396.

78. Chambon, M., Archimbaud, C., Bailly, J. L., et al. Circulation of enteroviruses and persistence of meningitis cases in the winter of 1999-2000. J Med Virol. 2001; 65 (2): 340-347.

79. de Crom, S. C., van Furth, M. A., Peeters, M. F., Rossen, J. W., and Obihara, C. C. Characteristics of pediatric patients with enterovirus meningitis and no cerebral fluid pleocytosis. Eur J Pediatr. 2012; 171 (5): 795-800.

80. McIntyre, J., and Keen, G. Laboratory surveillance of viral meningitis by examination of cerebrospinal fluid in Cape Town, 1981-9. Epidemiol Infect. 1993; 111 (2): 357-371.

81. Yeats, J., Smuts, H., Serfontein, C., and Kannemeyer, J. Investigation into a schoo enterovirus outbreak using PCR detection and serotype identification based on the $5^{\prime}$ noncoding region. Epidemiol Infect. 2005; 133 (6): 1123-1130.

82. Dumaidi, K., Frantzidou, F., Papa, A., Diza, E., and Antoniadis, A. Enterovirus meningitis in Greece from 2003-2005: diagnosis, CSF laboratory findings, and clinical manifestations. J Clin Lab Anal. 2006; 20 (5): 177-183.

83. Logotheti, M., Pogka, V., Horefti, E., et al. Laboratory investigation and phylogenetic analysis of enteroviruses involved in an aseptic meningitis outbreak in Greece during the summer of 2007. J Clin Virol. 2009; 46 (3): 270274.

84. Rahimi, P., Mahdian Naser, H., and Sohrabi, A. The association of non-polio Enteroviruses with aseptic meningitis in children in Iran. J Med Microbiol Infect Dis. 2014; 2 (2): 56-60.

85. Othman, I., Volle, R., Elargoubi, A., et al. Enterovirus meningitis in Tunisia (Monastir, Mahdia, 2011-2013): identification of virus variants cocirculating in France. Diagn Microbiol Infect Dis. 2016; 84 (2): 116-122.

86. Krasota, A., Loginovskih, N., Ivanova, O., and Lipskaya, G. Direct identification of Enteroviruses in cerebrospinal fluid of patients with suspected meningitis by nested PCR amplification. Viruses. 2016; 8 (1): 10.

87. Wieczorek, M., Figas, A., and Krzysztoszek, A. Enteroviruses associated with aseptic meningitis in
Poland, 2011-2014. Pol J Microbiol. 2016; 65 (2): 231-235.

88. Dumaidi, K., and Al-Jawabreh, A. Molecular detection and genotyping of enteroviruses from CSF samples of patients with suspected sepsis-like illness and/or aseptic meningitis from 2012 to 2015 in West Bank, Palestine. PLoS One. 2017; 12 (2): e0172357.

89. Ramalho, E., Sousa, I., Burlandy, F., et al. Identification and phylogenetic characterization of human enteroviruses isolated from cases of aseptic meningitis in Brazil, 2013-2017. Viruses. 2019; 11 (8): 690.

90. Harvala, H., McLeish, N., Kondracka, J., et al. Comparison of human parechovirus and enterovirus detection frequencies in cerebrospinal fluid samples collected over a 5 -year period in Edinburgh: HPeV type 3 identified as the most common picornavirus type. J Med Virol. 2011; 83 (5): 889-896.

91. Berk, M. C., Bruning, A. H., van WassenaerLeemhuis, A. G., Wolthers, K. C., and Pajkrt, D. Human parechovirus meningitis with adverse neurodevelopmental outcome: a case report. Pediatr Infect Dis J. 2018; 37 (10): e256-e257.

92. Rahimi, P., Naser, H. M., Siadat, S. D., et al. Genotyping of human parechoviruses in Iranian young children with aseptic meningitis and sepsislike illness. J Neurovirol. 2013; 19 (6): 595-600.

93. Michos, A. G., Syriopoulou, V. P., Hadjichristodoulou, C., et al. Aseptic meningitis in children: analysis of 506 cases. Plos One. 2007; 2 (8): e674.

94. Tan, N. W. H., Lee, E. Y., Khoo, G. M. C., Tee, N. W. S., Krishnamoorthy, S., and Choong, C. T. Cerebrospinal fluid white cell count: discriminatory or otherwise for enteroviral meningitis in infants and young children? J Neurovirol. 2016; 22 (2): 213-217.

95. Jansz, L., Buys, H., van Dijk, M., and Rohlwink, U. The profile of meningitis in a tertiary paediatric hospital in South Africa. S Afr J Child HIth. 2018; 12 (1): 15-20.

96. Lee, B. E., and Davies, H. D. Aseptic meningitis.

97. Karsch, K., Obermeier, P., Seeber, L., et al. Human parechovirus infections associated with seizures and rash in infants and toddlers. Pediatr Infect Dis J. 2015; 34 (10): 1049-1055.

98. Verboon-Maciolek, M., Groenendaal, F., Cowan, F., Govaert, P., van Loon, A., and de Vries, L. White matter damage in neonatal enterovirus meningoencephalitis. Neurol. 2008; 71 (7): 536.

99. Kolehmainen, P., Siponen, A., Smura, T., et al. Intertypic recombination of human parechovirus 4 isolated from infants with sepsis-like disease. J Clin Virol. 2017; 88: 1-7.

100. Bissel, S. J., Auer, R. N., Chiang, C-H., et al. Human parechovirus 3 meningitis and fatal leukoencephalopathy. J Neuropathol Experiment Neurol. 2015; 74 (8): 767-777.

101. Jones, M. Human parechovirus in infants: An emerging virus in Australia with severe neurodevelopmental implications. J Paediatr Child HIth. 2017; 53 (3): 306-308.

102. Obermeier, P. E., Karsch, K., Hoppe, C., et al. Acute disseminated encephalomyelitis after human parechovirus infection. Pediatr Infect Dis J. 2016; 35 (1): 35-38.

103. Negrini B, Kelleher KJ, Wald ER. Cerebrospinal fluid findings in aseptic versus bacterial meningitis. Pediatr. 2000; 105 (2): 316-319.

104. Sakushima, K., Hayashino, Y., Kawaguchi, T., Jackson, J. L., and Fukuhara, S. Diagnostic accuracy of cerebrospinal fluid lactate for differentiating bacterial meningitis from aseptic 
meningitis: a meta-analysis. J Infect. 2011; 62 (4): $255-262$

105. King, R. L., Lorch, S. A., Cohen, D. M., Hodinka, R. L, Cohn, K. A., and Shah, S. S. Routine cerebrospinal fluid enterovirus polymerase chain reaction testing reduces hospitalization and antibiotic use for infants 90 days of age or younger. Pediatr. 2007; 120 (3): 489-496.

106. Drysdale, S. B., and Kelly, D. F. Fifteen-minute consultation: enterovirus meningitis and encephalitis-when can we stop the antibiotics? Arch Dis Childhood-E. 2017; 102 (2): 66-71.

107. Wu, G., and Zaman, M. H. Low-cost tools for diagnosing and monitoring HIV infection diagnosis in low-resource settings. Bull World Health Org. 2012; 90: 914-920.

108. Wootton, S. H., Aguilera, E., Salazar, L., Hemmert, A. C., and Hasbun, R. Enhancing pathogen identification in patients with meningitis and a negative Gram stain using the BioFire FilmArray ${ }^{\circledR}$ Meningitis/Encephalitis panel. Ann Clin Microbiol Antimicrob. 2016; 15 (1): 26.

109. Messacar, K., Breazeale, G., Robinson, C. C, and Dominguez, S. R. Potential clinical impact of the film array meningitis encephalitis panel in children with suspected central nervous system infections. Diagn Microbiol Infect Dis. 2016; 86 (1): 118-120.

110. Chang, D., Okulicz, J. F., Nielsen, L. E, and White, B. K. A tertiary care center's experience with nove molecular meningitis/encephalitis diagnostics and implementation with antimicrobial stewardship. Mil Med. 2018; 183 (1-2): e24-e27.

111. Lee, S. H., Chen, S-Y., Chien, J-Y., Lee, T-F., Chen, J-M., and Hsueh, P-R. Usefulness of the FilmArray meningitis/encephalitis (M/E) panel for the diagnosis of infectious meningitis and encephalitis in Taiwan. J Microbiol Immunol Infect. 2019; 52 (5): 760- 768.

112. Soucek, D. K., Dumkow, L. E., VanLangen, K. M., and Jameson, A. P. Cost justification of the BioFire FilmArray meningitis/encephalitis panel versus standard of Care for Diagnosing Meningitis in a community hospital. J Pharm Pract. 2019; 32 (1): 36-40.

113. Tansarli, G. S., and Chapin, K. C. Diagnostic test accuracy of the BioFire $\AA$ FilmArray $\AA$ meningitis/ encephalitis panel: a systematic review and metaanalysis. Clin Microbiol Infect. 2020; 26 (3): 281290.

114. Llano López, L. H., Reischl, A. T., Gröndahl, B., et al. The BioFireFilmArray enables point of care diagnostic in neonatal parechovirus meningitis. Infect Dis. 2017; 49 (9): 705-707.
115. WHO. Guidelines on establishment of virology laboratory in developing countries. 2009.

116. Li, J-X., Song, Y-F., Wang, L., et al. Two-year efficacy and immunogenicity of Sinovac Enterovirus 71 vaccine against hand, foot and mouth disease in children. Expert Rev Vac. 2016; 15 (1): 129-137.

117. Lanko, K., Ma, Y., Delang, L., Mirabelli, C., and Neyts, J. Antiviral effects of selected nucleoside analogues against human parechoviruses A1 and A3. Antiviral Res. 2019; 162: 51-53.

118. Luchs, A., Russo, D. H., Cilli, A., et al. Echovirus 6 associated to aseptic meningitis outbreak, in São Joaquim da Barra, São Paulo, Brazil. Brazil J Microbiol. 2008; 39 (1): 28-31.

119. Lee, B. E., Chawla, R., Langley, J. M., et al. Paediatric Investigators Collaborative Network on Infections in Canada (PICNIC) study of aseptic meningitis. BMC Infect Dis. 2006; 6 (1): 68.

120. Chen, Y., Sun, Y., Yan, J., et al. Molecular epidemiology and prevalence of echovirus 30 in Zhejiang Province, China, from 2002 to 2015. J Microbiol Biotechnol. 2017; 27 (12): 2221-2227.

121. Archimbaud, C., Ouchchane, L., Mirand, A., et al. Improvement of the management of infants, children and adults with a molecular diagnosis of Enterovirus meningitis during two observational study periods. PLoS One. 2013; 8 (7): e68571.

122. Sasan, M. S., Alborzi, A., and Ziyaeyan, M. Epidemiology of aseptic meningitis in infants and children (shiraz-Iran). Arch Clin Infect Dis. 2012; 7 (4): 116-118.

123. Sadeghi, F., Talebi-Nesami, M., BarariSavadkouhi, R., Bijani, A., Ferdosi-Shahandashti, E., and Yahyapour, Y. Human enteroviruses in cerebrospinal fluid of children with suspected aseptic meningitis: A study in northern Iran. Caspian J Intern Med. 2017; 8 (2): 112.

124. De Crom, S., Obihara, C., de Moor, R., Veldkamp, E., van Furth, A., and Rossen, J. Prospective comparison of the detection rates of human enterovirus and parechovirus RT-qPCR and viral culture in different pediatric specimens. J Clin Virol. 2013; 58 (2): 449-454.

125. Choi, Y. J., Park, K. S., Baek, K. A., et al. Molecular characterization of echovirus 30associated outbreak of aseptic meningitis in Korea in 2008. J Microbiol Biotechnol. 2010; 20 (3): 643-649. 